\title{
Pollution, Ecological Risk and Source Identification of Heavy Metals in Sediments from the Huafei River in the Eastern Suburbso Kaifeng, China
}

\author{
Bingyan Jin \\ Henan University \\ Jinling Wang \\ Henan University \\ Wei Lou \\ Henan University \\ Liren Wang \\ Henan University \\ Jinlong Xu \\ Henan University \\ Jing Qian \\ Henan University \\ Dexin Liu ( $\nabla$ dxliu@vip.henu.edu.cn ) \\ Henan University \\ Jianbiao Peng \\ Henan Normal University \\ Qingxia Ma \\ Henan University
}

\section{Research Article}

Keywords: pollution, river, heavy, ecological, industrial, risk, metal, sources, term, huafei

Posted Date: July 7th, 2021

DOI: https://doi.org/10.21203/rs.3.rs-368427/v2

License: (c) (i) This work is licensed under a Creative Commons Attribution 4.0 International License.

Read Full License 


\title{
Pollution, ecological risk and source identification of heavy metals in sediments from the Huafei River in the eastern suburbs of Kaifeng, China
}

\author{
Bingyan Jin ${ }^{1}$, Jinling Wang ${ }^{1}$, Wei Lou ${ }^{1}$, Liren Wang ${ }^{1}$, Jinlong $\mathrm{Xu}{ }^{1}$, Jing Qian ${ }^{1}$, Dexin Liu ${ }^{1,2, *}$ \\ Jianbiao Peng ${ }^{3}$, Qingxia Ma ${ }^{1,2^{* *}}$ \\ 1. College of Environment and Planning, Henan University, 475004 Kaifeng, China
}

2. Key Laboratory of Geospatial Technology for the Middle and Lower Yellow River Regions, Ministry of Education,

Henan University, 475004 Kaifeng, China

3. School of Environment, Henan Normal University, 453007 Xinxiang, China

${ }^{*}$ Corresponding author.

** Corresponding author.

E-mail addresses: dxliu@vip.henu.edu.cn (D. Liu); mqx@henu.edu.cn (Q. Ma)

\begin{abstract}
Rivers in urban environments are significant components of their ecosystems but remain under threat of pollution from unchecked discharges of industrial sewage and domestic wastewater. Such river pollution, particularly over the longer term involving heavy metals, is an issue of worldwide concern regarding risks to the ecological environment and human health. In this study, we investigate the long-term pollution characteristics of the Huafei River, an important urban river in Kaifeng, China. River sedimentary samples were analyzed, assessing the degree and ecological risk of heavy metal pollution using the geo-accumulation index and potential ecological risk index methods; whilst Pearson's correlation, principal component, and cluster analyses were used to identify the sources of pollution. The results show that heavy metal concentrations are significantly higher than their corresponding fluvo-aquic soil background values in China, and the geo-accumulation indexes indicate, that of the 8 heavy metals identified, $\mathrm{Hg}$ is most prevalent, followed in sequence by
\end{abstract}


$\mathrm{Cd}>\mathrm{Zn}>\mathrm{Cu}>\mathrm{Pb}>\mathrm{Ni}>\mathrm{As}>\mathrm{Cr}$. The potential ecological risk index of the Huafei river is very high, with the potential ecological risk intensity highest in the midstream and downstream sections where it is recommended that pollution control is carried out, especially concerning $\mathrm{Hg}$ and $\mathrm{Cd}$. Long-term sequence analysis indicates that $\mathrm{Cu}$ and $\mathrm{Pb}$ dropped sharply from 1998 to 2017, but rebounded in 2019, and that $\mathrm{Zn}$ shows a continuous decreasing trend. Four main sources for the heavy metal contaminants were identified: $\mathrm{Cr}, \mathrm{Cu}, \mathrm{Ni}, \mathrm{Pb}, \mathrm{Zn}$ and $\mathrm{Hg}$ derived mainly from industrial activities, traffic sources and natural sources; Cd originated mainly from industrial and agricultural activities; whilst As was mainly associated with industrial activities. It is anticipated that the findings of this study will provide theoretical references for the effective control and scientific management of heavy metal pollution in the Huafei River and its surrounding areas.

\section{Introduction}

It is generally accepted that in urban environments, the prevalence of rivers are not only mere features of the landscape, in some instances they are of significant cultural importance, furthermore, they also form important components of urban ecosystems. Rivers provide a range of economic and social benefits including flood control and drainage, water supplies and sources of recreation to name but a few; moreover, as living ecosystems in their own right, urban rivers are of significance in the context of the wider ecological environment. However, urban rivers are under threat, especially from the acceleration of urbanization, which has a propensity for large amounts of industrial sewage and domestic wastewater to be discharged into them, resulting in the river becoming polluted, particularly concerning heavy metal pollution of river sediment ${ }^{1,2}$. At the junction of the liquid-solid two-phase interface, river sediment is an important part of the water environment. It is a reservoir for various pollutants in the water ${ }^{3,4}$ which, in effect, records changes 
in environmental information over time. Moreover, it is also an important carrier for studying the accumulation of heavy metals and persistent organic pollutants ${ }^{2,5}$ as well as being a medium for reviewing the ecological risks to the urban water environment ${ }^{5-7}$.

Heavy metals, with their immutable characteristics of non-biodegradability, toxicity and bioaccumulation, have a negative impact on the health of humans as well as ecosystems ${ }^{8-10}$ and, therefore, their occurrence in rivers needs to be strictly controlled. Consequently, this conclusion essentially stimulated further research activity into heavy metal pollution in river sediments which includes recent studies on heavy metal temporal and spatial distribution ${ }^{11,12}$, source identification ${ }^{13,14}$, pollution assessment ${ }^{5}$ and ecological restoration ${ }^{15}$. Although these studies, and others, have made progress, they are generally lacking in long-term research on both heavy metal accumulation and ecological risk. Currently, Hakanson's potential ecological risk index method ${ }^{16}$ is predominantly used in ecological risk assessments, although, in order to use it correctly in assessments, the potential ecological risk coefficient $(E)$ and potential ecological risk index (RI) grading standards must be adjusted according to the specific types and quantities of pollutants involved in the assessment ${ }^{17}$. However, existing studies mostly follow Hakanson's grading standard directly, that is, without any adjustments to $(E)$ and $(\mathrm{RI})^{18,19}$, thus affecting the reliability of the evaluation results. Nevertheless, despite established practice, our study included all necessary adjustments.

The Huafei River rises in northeast Kaifeng; its water sources are mainly from the Yellow River, but includes industrial wastewater and domestic sewage, etc. Thus, it is an important river in terms of urban landscape, flood discharge and sewage discharge. Moreover, there is a large area of cultivated land in the east of the Huafei River, so it is also an important river for agricultural 
irrigation but has had a history of sewage pollution for some 58 years. Irrigated areas, which have been polluted by the Huafei River for a long time, have seen their soils subjected to the continuous accumulation of heavy metals, significantly threatening the soil, ecological environment, and consequently human health ${ }^{13,20,21}$. Since the end of the 20th century, the author's research group has focused research attention on the Huafei River and the associated areas irrigated by sewage, and has carried out a series of studies on heavy metal pollution, including heavy metal pollution of the soilcrop system in the areas irrigated by sewage ${ }^{22}$, the responses of local fauna to heavy metal pollution in the areas irrigated by sewage $\mathrm{e}^{23}$, heavy metal pollution in soil of the areas irrigated by sewage $\mathrm{e}^{24}$ and heavy metal pollution of the sediment in the Huafei River ${ }^{15,25}$, etc. The objectives of this paper were (1) to collect sediment samples from the Huafei River to determine and analyze their physical and chemical properties $\{\mathrm{pH}$, organic matter $(\mathrm{OM})$, total nitrogen $(\mathrm{TN})$ and total phosphorus $(\mathrm{TP})\}$ and the prevalence of 8 heavy metals ( $\mathrm{As}, \mathrm{Cd}, \mathrm{Cr}, \mathrm{Cu}, \mathrm{Hg}, \mathrm{Ni}, \mathrm{Pb}$ and $\mathrm{Zn}$ ); (2) to evaluate the degree of contamination and assess the ecological risks in the river by calculating the geo-accumulation index and potential ecological risk index, recalling the data on heavy metals in research over the last 20 years; (3) to identify the possible sources of these heavy metals based on Pearson's correlation analysis, principal component analysis and cluster analysis. It is anticipated that the findings of this study will provide theoretical references for the effective control and scientific management of heavy metal pollution in the Huafei River and its surrounding areas.

\section{Materials and methods}

Study area. The study area in the Kaifeng basin is in the east-central region of Henan province, China, on the northeast to southwest sloping plain area, which is midstream and downstream of the Yellow River. The region is characterized by a temperate monsoon climate, with an average annual 
temperature of $14{ }^{\circ} \mathrm{C}$ and precipitation of $627.5 \mathrm{~mm}$, which is mainly concentrated in the period between July to August. The parent material of the soil in Kaifeng is alluvium from the Yellow River, and the main soil type is fluvo-aquic soil ${ }^{21}$. Within the study area, the Huafei River was selected for investigation because it is subject to industrial wastewater discharges from a range of sources including the Kaifeng fertilizer plant, paper factory, instrument manufacturer, pharmaceutical factory, zinc smelting plant, and the Kaifeng carbon enterprise ${ }^{25}$. Also known as Dongjiao Furrow, the Huafei River flows from north to south into the Huiji River, which is a tributary of the Huaihe River, in the southeast of Kaifeng City. The Huafei River is approximately $15 \mathrm{~km}$ long with an average velocity of $0.4 \mathrm{~m} \cdot \mathrm{s}^{-1}$, an average depth of $0.67 \mathrm{~m}$, a width of $3.98 \mathrm{~m}$, a bed gradient of one in 4,000 , and a basin area of about $30 \mathrm{~km}^{2}$.

Sample collection and analysis. A total of 24 surface sediment samples were collected using a clamshell grab in November 2019, including 3 from the cut-flow sections and 21 from polluted sections. The locations of all sampling sites were determined using the global positioning system and are shown in Fig. 1. Collected from the middle of the riverbed at a depth of $0.2 \mathrm{~m}$, the sediment samples comprising a mixture of minerals, clay, and organic matter were stored in clean zip-bags and then transferred to the laboratory. After air-drying, stones and plant materials were removed from the sediment samples which subsequently were ground and passed through a 1-mm nylon screen in preparation for both physical and chemical property analysis. In addition, an agate mortar and pestle were used to grind a quarter of the total samples, which were then filtered through a 0.149-mm nylon screen for measuring the heavy metals.

Following collection and preparation, the samples were analyzed as follows: Sediment $\mathrm{pH}$ was determined using a pH meter. $\mathrm{OM}$ and $\mathrm{TN}$ were determined by means of the potassium dichromate 
and Kjeldahl methods, respectively. After the samples were digested by $\mathrm{HClO}_{4}-\mathrm{H}_{2} \mathrm{SO}_{4}$, the ammonium molybdate spectrophotometric method was used to measure TP. Once the samples were whole digested using the $\mathrm{HNO}_{3}-\mathrm{HClO}_{4}-\mathrm{HF}$ method, the concentrations of $\mathrm{Cd}, \mathrm{Cu}, \mathrm{Ni}, \mathrm{Pb}$ and $\mathrm{Zn}$ were measured using an inductively coupled plasma-atomic emission spectrometer (ICP-AES, Thermos Scientific, USA). When the soil samples were digested with $\mathrm{HNO}_{3}: \mathrm{HCl}=1: 3$, we used atomic fluorescence spectrometry (AFS, AFS-3100, Skyray Instrument, China) to analyze the concentrations of As and $\mathrm{Hg}$. The soil samples were digested with mixed acids $\left(\mathrm{HNO}_{3}-\mathrm{HCl}-\mathrm{HF}-\right.$ $\mathrm{HClO}_{4}$ ), after that $\mathrm{Cr}$ concentration was determined by Flame atomic absorption spectrometry (FAAS, AA-6601F, Shimadzu, Japan). Furthermore, the national standard soil reference material (GSS-2), repeat analyses and blank analyses were incorporated into the analytical process to test the accuracy of the measurement results. The results showed that the analytical error of parallel samples was less than $5 \%$, and the recovery rate of each element was between 90.58 and $112.06 \%$, which was consistent with quality control requirements. 


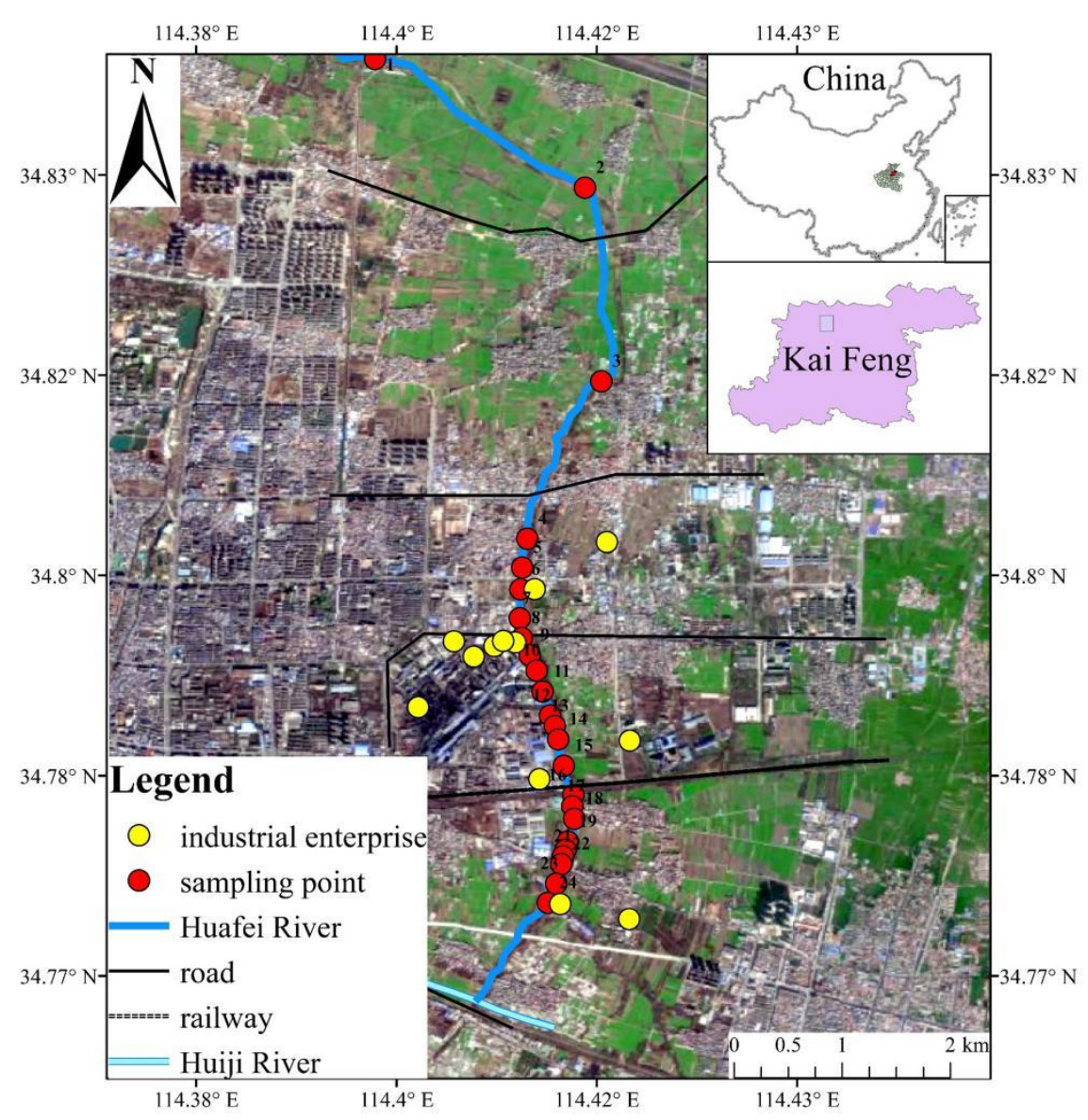

Figure 1. Sampling location map of the study area.

Assessment of contaminations in sediment. Assessments of contamination in the sediment samples were carried out using two well-known indexes, namely, the Geo-accumulation index, and the Potential ecological risk index. Their descriptions and particular application in the study are as follows:

The geo-accumulation index $\left(I_{g e o}\right)$ is a quantitative index as defined by Müller ${ }^{26}$ and is widely used to assess heavy metal pollution in sediments of rivers and lakes ${ }^{27-29}$. The equation for calculating $I_{\text {geo }}$ is as follows:

$$
I_{\text {geo }}=\log _{2}\left[C_{i} /\left(k \times B_{i}\right)\right]
$$

Where $C_{i}$ is the measured concentration of element $i$ in the sediment, and $B_{i}$ is the geo-chemical background value of element $i$. In this study, soil in Kaifeng has obvious texture levels and the 
parent material of the soil is alluvial material from the Yellow River. The soil type is mainly yellow tidal soil, hence, the background value for the Chinese tidal soil element is adopted in this study ${ }^{30}$. $k$ is a constant (and generally takes on a value of 1.5) to minimize the effect of possible variations in the crustal contribution to sediments ${ }^{31}$. The $I_{\text {geo }}$ is categorized into 7 classes as shown in Table 1.

Table 1. The geo-accumulation index classification standard.

\begin{tabular}{lll}
\hline The geo-accumulation index $\left(I_{\text {geo }}\right)$ & Class & Pollution level \\
\hline$I_{\text {geo }} \leq 0$ & 0 & Unpolluted \\
$0<I_{g e o} \leq 1$ & 1 & From unpolluted to moderately polluted \\
$1<I_{g e o} \leq 2$ & 2 & Moderately polluted \\
$2<I_{g e o} \leq 3$ & 3 & From moderately to strongly polluted \\
$3<I_{g e o} \leq 4$ & 4 & Strongly polluted \\
$4<I_{g e o} \leq 5$ & 5 & From strongly to extremely polluted \\
$I_{g e o}>5$ & 6 & Extremely polluted \\
\hline
\end{tabular}

From the sedimental perspective, the RI proposed by Hakanson ${ }^{16}$ was used to evaluate the heavy metal pollution in the sediments according to the heavy metal properties and environmental behavior characteristics. The content of each heavy metal, the toxicity level, environmental effect, and comprehensive pollution degree of the heavy metals were all considered. The equations for the calculations are as follows:

$$
\begin{gathered}
E_{r}^{i}=T_{r}^{i} \times \frac{C_{s}^{i}}{C_{n}^{i}} \\
\mathrm{RI}=\sum_{i=1}^{n} E_{r}^{i}=\sum_{i=1}^{n} T_{r}^{i} \times C_{f}^{i}=\sum_{i=1}^{n} T_{r}^{i} \times \frac{C_{s}^{i}}{C_{n}^{i}}
\end{gathered}
$$

Where $E_{r}^{i}$ is the potential ecological risk factor of the heavy metal $i, C_{s}^{i}$ is the measured concentration of metal $i, C_{n}^{i}$ is the geo-chemical background value for metal $i$, as adopted from the fluvo-aquic soil background values in China ${ }^{30}$ (Table 2), $T_{r}^{i}$

Table 2. The geo-chemical background value $C_{n}^{i}$ and the toxic response factor $T_{r}^{i}$.

\begin{tabular}{lll}
\hline Heavy metal & The background value $C_{n}^{i} /\left(\mathrm{mg} \cdot \mathrm{kg}^{-1}\right)$ & The toxic effect factor $T_{r}^{i}$ \\
\hline $\mathrm{Hg}$ & 0.032 & 40 \\
$\mathrm{Cd}$ & 0.09 & 30 \\
$\mathrm{As}$ & 9.30 & 10 \\
\hline
\end{tabular}




\begin{tabular}{lll}
\hline $\mathrm{Cu}$ & 22.90 & 5 \\
$\mathrm{~Pb}$ & 20.60 & 5 \\
$\mathrm{Ni}$ & 28.10 & 5 \\
$\mathrm{Cr}$ & 64.81 & 2 \\
$\mathrm{Zn}$ & 67.80 & 1 \\
\hline
\end{tabular}

is the toxic effect factor for metal $i$, and $n$ is the number of metals at the site. According to the relevant study ${ }^{21}$, the toxic effect factors for $\mathrm{Hg}, \mathrm{Cd}, \mathrm{As}, \mathrm{Cu}, \mathrm{Pb}, \mathrm{Ni}, \mathrm{Cr}$, and $\mathrm{Zn}$ are 40, 30, 10, 5, 5, 5,2 , and 1 , respectively. RI is the index of comprehensive potential ecological risk. Regarding data published in previous studies ${ }^{17,21}$, this study re-adjusted the $E$ and RI classification standards. The $E$ classification's upper limit of the first risk level was obtained by multiplying the non-polluting pollution coefficient $(C=1)$ along with the maximum toxicity coefficient of the pollutant under evaluation, in addition, the upper limit values of other levels can be obtained by multiplying the upper limit of its previous level by 2 . Among the 8 heavy metals in this study, the $T$ value of $\mathrm{Hg}$ was the largest (40), and was used as the first class's upper limit. Therefore, the classification standard of $E$ was obtained. Then the RI classification standard was re-adjusted as follows: first, according to Hakanson's first upper limit value (150) we divided by the sum value of the toxicity coefficients of 8 pollutants (133), thereby, the RI classification value of unit toxicity coefficient (1.13) was obtained. This value was then multiplied by the sum value of the toxicity coefficients of the 8 heavy metals in this study (98), followed by rounding to the nearest integer of tens place $(1.13 \times 98=110.74$ $\approx 110$ ) to obtain the first-order classification value. Finally, the classification value of other levels was obtained by multiplying the first-order classification value by 2 (Table 3 ).

Table 3. The adjusted $E$ and RI classification standards.

\begin{tabular}{llll}
\hline$E$ value & Ecological risk levels of a single metal & RI value & Ecological risk levels to the environment \\
\hline$<40$ & Low ecological risk & $<110$ & Low ecological risk \\
$40 \sim 80$ & Moderate ecological risk & $110 \sim 220$ & Moderate ecological risk \\
\hline
\end{tabular}




\begin{tabular}{llll}
\hline $80 \sim 160$ & Considerable ecological risk & $220 \sim 440$ & Considerable ecological risk \\
$160 \sim 320$ & High ecological risk & $\geq 440$ & Very high ecological risk \\
$\geq 320$ & Very high ecological risk & & \\
\hline
\end{tabular}

\section{Results}

Physicochemical properties and heavy metal contents in the sediments from the Huafei River.

As shown in Table 4, the $\mathrm{pH}$ of the surface sediments from the Huafei River range from 7.31 to 8.23, and the contents of TN, OM and TP range from 587.65 to $5401.84 \mathrm{mg} \cdot \mathrm{kg}^{-1}, 472.63$ to 13122.10 $\mathrm{mg} \cdot \mathrm{kg}^{-1}, 344.81$ to $1496.07 \mathrm{mg} \cdot \mathrm{kg}^{-1}$, respectively, with an average content of 2089.76

Table 4. Values of physicochemical properties in sediments of the Huafei River.

\begin{tabular}{lllll}
\hline & $\mathrm{pH}$ & $\mathrm{TN}\left(\mathrm{mg} \cdot \mathrm{kg}^{-1}\right)$ & $\mathrm{OM}\left(\mathrm{mg} \cdot \mathrm{kg}^{-1}\right)$ & $\mathrm{TP}\left(\mathrm{mg} \cdot \mathrm{kg}^{-1}\right)$ \\
\hline Average & 7.73 & 2089.76 & 5932.59 & 786.58 \\
Maximum & 8.23 & 5401.84 & 13122.10 & 1496.07 \\
Minimum & 7.31 & 587.65 & 472.63 & 344.81 \\
\hline
\end{tabular}

$\mathrm{mg} \cdot \mathrm{kg}^{-1}, 5932.59 \mathrm{mg} \cdot \mathrm{kg}^{-1}$ and $786.58 \mathrm{mg} \cdot \mathrm{kg}^{-1}$. As presented in Table 5, the average contents of As, $\mathrm{Cd}, \mathrm{Cr}, \mathrm{Cu}, \mathrm{Hg}, \mathrm{Ni}, \mathrm{Pb}$ and $\mathrm{Zn}$ were 26.62, 50.76, 97.08, 292.37, 10.01, 50.13, 238.59 and 1335.12 $\mathrm{mg} \cdot \mathrm{kg}^{-1}$, respectively, which were $2.86,563.99,1.50,12.77,312.82,1.78,11.58$ and 19.69 times the background value of fluvo-aquic soil ${ }^{30}$. As shown in Fig. 2, The most serious pollution with $\mathrm{Cd}$, $\mathrm{Cr}, \mathrm{Cu}, \mathrm{Hg}, \mathrm{Ni}, \mathrm{Pb}$ and $\mathrm{Zn}$ was found at sites 5-7, 9-10 and 15-17, which were located in the midstream and downstream sections of the river. The highest concentration of As occurred in sites 17-24, which were located in the downstream section of the river.

Table 5. Descriptive statistics of heavy metal concentrations $\left(\mathrm{mg} \cdot \mathrm{kg}^{-1}\right)$.

\begin{tabular}{lllllllll}
\hline & $\mathrm{As}$ & $\mathrm{Cd}$ & $\mathrm{Cr}$ & $\mathrm{Cu}$ & $\mathrm{Hg}$ & $\mathrm{Ni}$ & $\mathrm{Pb}$ & $\mathrm{Zn}$ \\
\hline Average & 26.62 & 50.76 & 97.08 & 292.37 & 10.01 & 50.13 & 238.59 & 1335.12 \\
Maximum & 100.04 & 371.47 & 160.97 & 866.90 & 56.92 & 101.35 & 745.76 & 4206.97 \\
Minimum & 4.91 & 0.15 & 23.13 & 7.70 & 0.40 & 11.33 & 2.80 & 50.00 \\
SD & 30.18 & 89.11 & 31.23 & 275.65 & 13.68 & 21.51 & 262.88 & 1394.02
\end{tabular}




$\begin{array}{lllllllll}\mathrm{CV}(\%) & 113 & 176 & 32 & 94 & 137 & 43 & 110 & 104\end{array}$

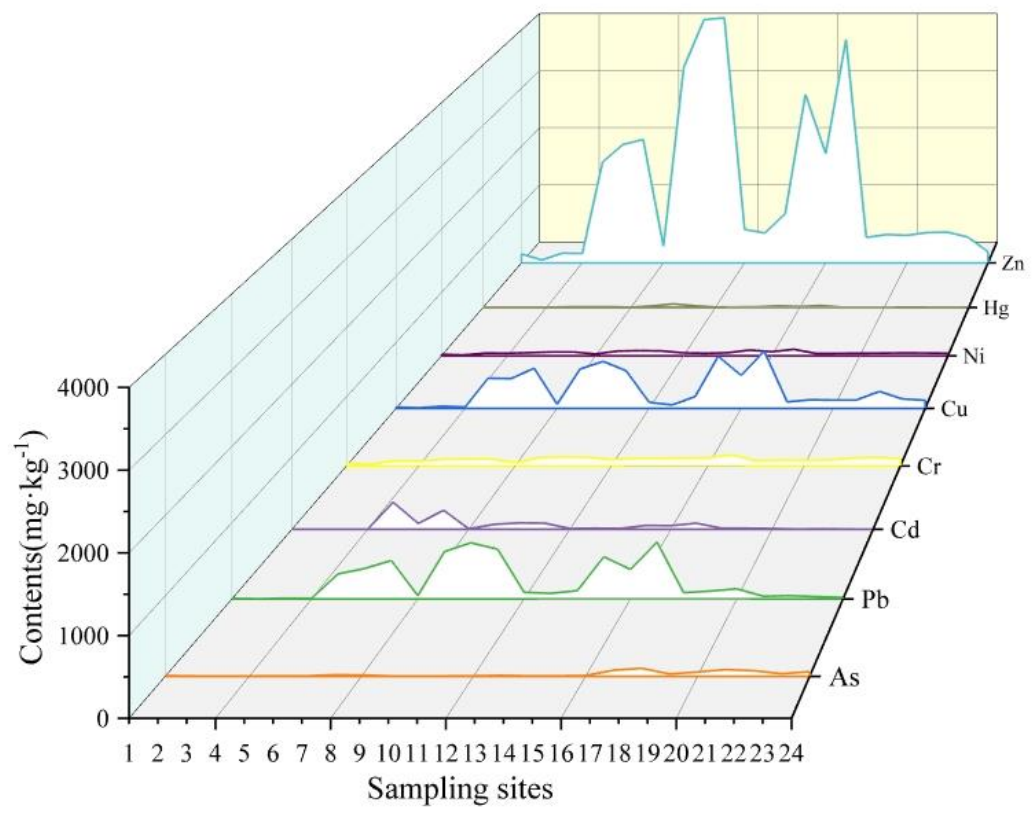

Figure 2. The contents of heavy metals in the sediments from the Huafei River.

The coefficients of variation (CV) of $\mathrm{Cd}, \mathrm{Hg}, \mathrm{As}, \mathrm{Pb}, \mathrm{Zn}$ and $\mathrm{Cu}$ were high, measuring $176 \%$, $137 \%, 113 \%, 110 \%, 104 \%$ and $94 \%$, respectively (Table 5), indicating that the spatial differences of heavy metal contents in the river sediment are large, and the accumulation of these heavy metals in river sediment has been significantly affected by human activities.

Pollution and risk assessment of heavy metals in the sediments. The calculation results of the geo-accumulation index for eight heavy metals found in the sediments of the Huafei River are shown in Table 6. The sequence of the average $I_{\text {geo }}$ from high to low is $\mathrm{Hg}(6.36)>\mathrm{Cd}(6.12)>\mathrm{Zn}(2.81)>$ $\mathrm{Cu}(2.19)>\mathrm{Pb}(1.61)>\mathrm{Ni}(0.11)>\mathrm{As}(0.07)>\mathrm{Cr}(-0.10)$. Both $\mathrm{Hg}$ and $\mathrm{Cd}$ exhibited as extremely polluted (class 6), the highest pollution level, and about $71 \%$ of the sampling sites are polluted with this classification. Contaminations with $\mathrm{Zn}$ and $\mathrm{Cu}$ exhibited as moderately to strongly polluted (class 3), and about $21 \%$ and $25 \%$ of the sampling sites fluctuated from strongly to extremely polluted by $\mathrm{Zn}$ and $\mathrm{Cu}$ (grade 5), respectively. Contaminations with $\mathrm{Pb}$ are classed as moderately polluted, with about $13 \%$ and $25 \%$ of the sampling sites being strongly polluted and strongly- 
extremely polluted, respectively. In contrast, As pollution is relatively light (the mean value of $I_{g e o}$ was 0.07 ), and the $I_{g e o}$ class of $\mathrm{Cr}$ and $\mathrm{Ni}$ in the Huafei River is 0 and 1, respectively, suggesting that most sections of the river remain relatively clean. The sequence of average $I_{g e o}$ also indicates that the heavy metals $\mathrm{Hg}$ and $\mathrm{Cd}$ contribute the most to the geo-accumulation index.

Table 6. Heavy metal accumulation index and classification of sediment at each sampling site.

\begin{tabular}{|c|c|c|c|c|c|c|c|c|c|c|c|c|c|c|c|c|c|c|}
\hline & $\mathrm{Cd}$ & & $\mathrm{Cr}$ & & $\mathrm{Cu}$ & & $\mathrm{Ni}$ & & $\mathrm{Pb}$ & & $\mathrm{Zn}$ & & $\mathrm{Hg}$ & & As & & \multicolumn{2}{|c|}{$I_{g e o}$ average } \\
\hline $\begin{array}{c}\text { Sampling } \\
\text { points }\end{array}$ & $I_{g e o}$ & $\mathrm{C}$ & $I_{g e o}$ & $\mathrm{C}$ & $I_{g e o}$ & $\mathrm{C}$ & $I_{g e o}$ & $\mathrm{C}$ & $I_{g e o}$ & $\mathrm{C}$ & $I_{g e o}$ & $\mathrm{C}$ & $I_{g e o}$ & $\mathrm{C}$ & $I_{g e o}$ & $\mathrm{C}$ & $I_{g e o}$ & $\mathrm{C}$ \\
\hline 1 & 0.89 & 1 & -1.29 & 0 & -0.80 & 0 & -0.98 & 0 & -1.89 & 0 & 0.58 & 1 & 3.44 & 4 & -0.63 & 0 & -0.08 & 0 \\
\hline 2 & 1.86 & 2 & -2.07 & 0 & -2.16 & 0 & -1.90 & 0 & -3.46 & 0 & -1.02 & 0 & 4.14 & 5 & -1.39 & 0 & -0.75 & 0 \\
\hline 3 & 0.17 & 1 & -0.34 & 0 & -0.03 & 0 & -0.02 & 0 & -1.59 & 0 & 0.72 & 1 & 3.54 & 4 & -1.41 & 0 & 0.13 & 1 \\
\hline 4 & 1.74 & 2 & -0.45 & 0 & -0.75 & 0 & -0.09 & 0 & -1.64 & 0 & 0.67 & 1 & 3.17 & 4 & -1.50 & 0 & 0.14 & 1 \\
\hline 5 & 11.43 & 6 & -0.02 & 0 & 3.73 & 4 & 0.18 & 1 & 3.41 & 4 & 4.09 & 5 & 7.27 & 6 & -1.03 & 0 & 3.63 & 4 \\
\hline 6 & 9.20 & 6 & 0.05 & 1 & 3.72 & 4 & 0.50 & 1 & 3.69 & 4 & 4.32 & 5 & 7.66 & 6 & -1.40 & 0 & 3.47 & 4 \\
\hline 7 & 10.92 & 6 & 0.09 & 1 & 4.14 & 5 & 0.49 & 1 & 4.03 & 5 & 4.38 & 5 & 7.67 & 6 & 0.48 & 1 & 4.02 & 5 \\
\hline 8 & 5.10 & 6 & -1.08 & 0 & 0.86 & 1 & -0.61 & 0 & 0.49 & 1 & 1.49 & 2 & 4.63 & 5 & 0.32 & 1 & 1.40 & 2 \\
\hline 9 & 8.96 & 6 & 0.31 & 1 & 4.12 & 5 & 0.80 & 1 & 4.33 & 5 & 5.04 & 6 & 8.91 & 6 & -1.41 & 0 & 3.88 & 4 \\
\hline 10 & 9.32 & 6 & 0.45 & 1 & 4.37 & 5 & 0.93 & 1 & 4.58 & 5 & 5.36 & 6 & 10.21 & 6 & -1.51 & 0 & 4.22 & 5 \\
\hline 11 & 9.26 & 6 & 0.38 & 1 & 4.05 & 5 & 0.85 & 1 & 4.40 & 5 & 5.37 & 6 & 9.14 & 6 & -1.40 & 0 & 4.01 & 5 \\
\hline 12 & 6.16 & 6 & -0.06 & 0 & 1.41 & 2 & 0.09 & 1 & 1.49 & 2 & 2.50 & 3 & 6.27 & 6 & -1.03 & 0 & 2.10 & 3 \\
\hline 13 & 6.61 & 6 & 0.16 & 1 & 0.61 & 1 & -0.12 & 0 & 1.27 & 2 & 2.33 & 3 & 7.05 & 6 & -0.20 & 0 & 2.21 & 3 \\
\hline 14 & 6.25 & 6 & 0.22 & 1 & 2.38 & 3 & 0.17 & 1 & 1.82 & 2 & 3.05 & 4 & 7.69 & 6 & -1.28 & 0 & 2.54 & 3 \\
\hline 15 & 8.59 & 6 & 0.24 & 1 & 4.52 & 5 & 1.09 & 2 & 4.16 & 5 & 4.83 & 5 & 9.05 & 6 & -1.16 & 0 & 3.91 & 4 \\
\hline 16 & 8.49 & 6 & 0.28 & 1 & 3.86 & 4 & 0.60 & 1 & 3.65 & 4 & 4.21 & 5 & 8.21 & 6 & -0.47 & 0 & 3.60 & 4 \\
\hline 17 & 9.27 & 6 & 0.73 & 1 & 4.66 & 5 & 1.27 & 2 & 4.59 & 5 & 5.24 & 6 & 9.31 & 6 & 2.47 & 3 & 4.69 & 5 \\
\hline 18 & 6.71 & 6 & -0.35 & 0 & 1.51 & 2 & -0.24 & 0 & 1.43 & 2 & 2.10 & 3 & 5.81 & 6 & 2.84 & 3 & 2.48 & 3 \\
\hline 19 & 6.62 & 6 & -0.14 & 0 & 1.93 & 2 & -0.17 & 0 & 1.75 & 2 & 2.26 & 3 & 5.42 & 6 & 1.08 & 2 & 2.34 & 3 \\
\hline 20 & 6.13 & 6 & -0.20 & 0 & 1.88 & 2 & -0.12 & 0 & 2.12 & 3 & 2.22 & 3 & 5.50 & 6 & 1.98 & 2 & 2.44 & 3 \\
\hline 21 & 3.42 & 4 & -0.16 & 0 & 1.87 & 2 & -0.04 & 0 & 0.21 & 1 & 2.36 & 3 & 5.32 & 6 & 2.60 & 3 & 1.95 & 2 \\
\hline 22 & 5.46 & 6 & 0.24 & 1 & 2.90 & 3 & 0.08 & 1 & 0.49 & 1 & 2.37 & 3 & 4.97 & 5 & 2.35 & 3 & 2.36 & 3 \\
\hline 23 & 3.21 & 4 & 0.35 & 1 & 2.07 & 3 & 0.02 & 1 & 0.01 & 1 & 2.12 & 3 & 3.04 & 4 & 1.23 & 2 & 1.51 & 2 \\
\hline 24 & 1.15 & 2 & 0.15 & 1 & 1.84 & 2 & -0.10 & 0 & -0.62 & 0 & 0.90 & 1 & 5.31 & 6 & 2.08 & 3 & 1.34 & 2 \\
\hline$I_{\text {geo average }}$ & 6.12 & 6 & -0.10 & 0 & 2.19 & 3 & 0.11 & 1 & 1.61 & 2 & 2.81 & 3 & 6.36 & 6 & 0.07 & 1 & 2.40 & 3 \\
\hline
\end{tabular}

Note: $\mathrm{C}$ is for the classification of $I_{g e o .}$

Spatially, heavy metal contaminations, as shown in Fig. 3, are the most severe in sites 7, 10, 11 and 16, reaching class 5 (strong to extremely polluted); followed by sites $5,6,9,15$ and 16 , which are strongly polluted by these heavy metal s (class 4 ). The pollution degree at sites 12,13 , 
$14,18,19,20$ and 22 reached class 3 (moderately to strong polluted). In general, the pollution in the midstream and downstream sections of the Huafei River are the most serious.

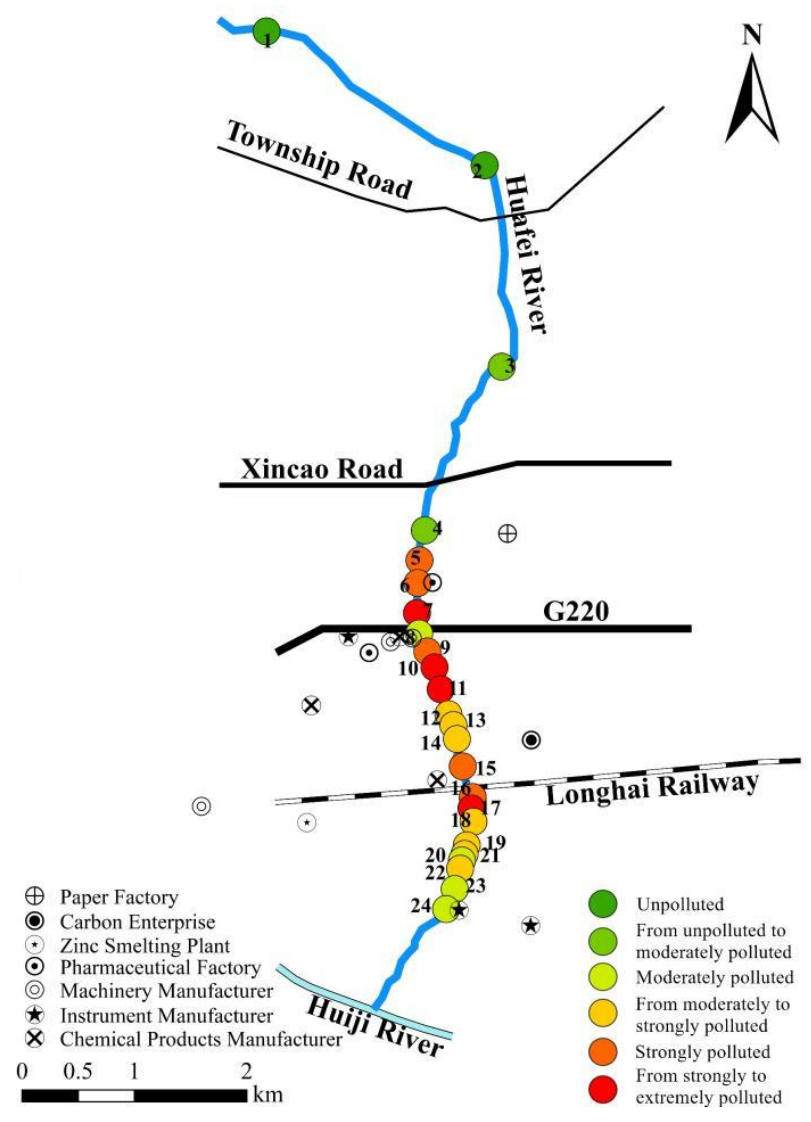

Figure 3. Spatial distribution of geo-accumulation indexes of heavy metals in sediments from the Huafei River.

The sequence of the average $E$ values for the eight heavy metals from high to low are $\mathrm{Cd}$ $(16919.71)>\mathrm{Hg}(12512.80)>\mathrm{Cu}(63.84)>\mathrm{Pb}(57.91)>\mathrm{As}(28.62)>\mathrm{Zn}(19.69)>\mathrm{Ni}(8.92)>\mathrm{Cr}$ (3.00). Overall, $\mathrm{Hg}$ and $\mathrm{Cd}$ are at very high ecological risk levels, and all sampling sites identifying $\mathrm{Hg}$ and $79 \%$ of sampling sites registering $\mathrm{Cd}$ show a very high ecological risk. The average $E$ value of $\mathrm{Cu}$ and $\mathrm{Pb}$ is at a moderate risk level, of which $58 \%$ of the sampling sites of $\mathrm{Cu}$ and $62.5 \%$ of the sampling sites of $\mathrm{Pb}$ are at a low ecological risk level, while sites 15 and 17 registered $\mathrm{Cu}$ and sites 10 and 17 recorded a high ecological risk level. The $E$ mean values of the other four heavy metal elements (As, $\mathrm{Cr}, \mathrm{Ni}$ and $\mathrm{Zn}$ ) are at a low ecological risk level, as is the case with more than $75 \%$ 
of the sampling sites, including the levels of $\mathrm{Ni}$ and $\mathrm{Cr}$ at all sampling sites.

The comprehensive potential ecological risk index (RI) of the study area ranges from 715.30 to 133338.38 , with an average value of 29614.48 , indicating that the study area is critically in a very high ecological risk level (Table 7). In summary, the results of the potential ecological risk assessments indicate that pollution control should be carried out in the midstream and downstream sections of the river, with a focus on targeting $\mathrm{Hg}$ and $\mathrm{Cd}$.

Table 7. The potential ecological risk indexes of heavy metals in sediments from the Huafei River.

\begin{tabular}{|c|c|c|c|c|c|c|c|c|c|}
\hline Samping points & $\mathrm{Cd}$ & $\mathrm{Cr}$ & $\mathrm{Cu}$ & $\mathrm{Ni}$ & $\mathrm{Pb}$ & $\mathrm{Zn}$ & $\mathrm{Hg}$ & As & RI \\
\hline 1 & 83.42 & 1.22 & 4.31 & 3.81 & 2.02 & 2.24 & 652.60 & 9.72 & 759.34 \\
\hline 2 & 163.88 & 0.71 & 1.68 & 2.02 & 0.68 & 0.74 & 1060.19 & 5.73 & 1235.63 \\
\hline 3 & 50.47 & 2.36 & 7.34 & 7.41 & 2.49 & 2.46 & 698.61 & 5.66 & 776.81 \\
\hline 4 & 150.05 & 2.20 & 4.46 & 7.05 & 2.41 & 2.38 & 541.47 & 5.29 & 715.30 \\
\hline 5 & 123823.82 & 2.96 & 99.71 & 8.50 & 79.91 & 25.53 & 9290.63 & 7.34 & 133338.38 \\
\hline 6 & 26556.22 & 3.11 & 98.52 & 10.63 & 97.04 & 29.96 & 12124.13 & 5.69 & 38925.30 \\
\hline 7 & 87100.00 & 3.19 & 132.64 & 10.52 & 122.45 & 31.24 & 12199.62 & 20.86 & 99620.51 \\
\hline 8 & 1545.36 & 1.42 & 13.61 & 4.91 & 10.53 & 4.21 & 1485.98 & 18.67 & 3084.70 \\
\hline 9 & 22482.55 & 3.72 & 130.39 & 13.08 & 150.52 & 49.50 & 28908.59 & 5.65 & 51744.02 \\
\hline 10 & 28851.26 & 4.11 & 155.27 & 14.34 & 178.78 & 61.56 & 71146.54 & 5.28 & 100417.14 \\
\hline 11 & 27645.11 & 3.91 & 124.38 & 13.47 & 158.43 & 62.05 & 33870.61 & 5.69 & 61883.64 \\
\hline 12 & 3213.45 & 2.88 & 19.91 & 7.96 & 21.12 & 8.46 & 4638.47 & 7.33 & 7919.60 \\
\hline 13 & 4395.60 & 3.36 & 11.48 & 6.88 & 18.08 & 7.57 & 7937.35 & 13.04 & 12393.36 \\
\hline 14 & 3416.67 & 3.49 & 38.96 & 8.45 & 26.54 & 12.42 & 12375.63 & 6.17 & 15888.32 \\
\hline 15 & 17298.11 & 3.55 & 172.19 & 15.95 & 134.31 & 42.64 & 31768.86 & 6.69 & 49442.29 \\
\hline 16 & 16201.86 & 3.65 & 108.95 & 11.33 & 94.01 & 27.67 & 17757.24 & 10.82 & 34215.53 \\
\hline 17 & 27816.55 & 4.97 & 189.28 & 18.03 & 181.01 & 56.57 & 38051.43 & 82.91 & 66400.76 \\
\hline 18 & 4719.18 & 2.35 & 21.34 & 6.35 & 20.27 & 6.44 & 3356.16 & 107.57 & 8239.66 \\
\hline
\end{tabular}




\begin{tabular}{lllllllllll}
\hline 19 & 4427.86 & 2.72 & 28.54 & 6.65 & 25.15 & 7.18 & 2574.30 & 31.76 & 7104.16 \\
20 & 3154.05 & 2.61 & 27.52 & 6.92 & 32.49 & 6.98 & 2723.45 & 59.18 & 6013.20 \\
21 & 482.37 & 2.69 & 27.43 & 7.29 & 8.65 & 7.68 & 2400.77 & 90.72 & 3027.60 \\
22 & 1979.37 & 3.55 & 55.97 & 7.92 & 10.54 & 7.78 & 1875.00 & 76.45 & 4016.58 \\
23 & 416.25 & 3.84 & 31.39 & 7.60 & 7.57 & 6.54 & 493.95 & 35.10 & 1002.23 \\
24 & 99.60 & 3.33 & 26.77 & 7.00 & 4.87 & 2.80 & 2375.63 & 63.58 & 2583.57 \\
\hline
\end{tabular}

\section{Discussion}

The change characteristics of the content of heavy metals in the Huafei River sediment over a long-time scale are shown in Fig. 4. Fig. 4 displays heavy metal data (used in this paper) from studies conducted in: $1998^{20}, 2015^{25}, 2017^{13}$ and 2019. As can be seen in Fig. 4, the concentrations of $\mathrm{Cu}$ and $\mathrm{Pb}$ decreased significantly in the period 1998 to 2017, and the content of $\mathrm{Zn}$ also shows a continuous decreasing trend. These decreases can be attributed

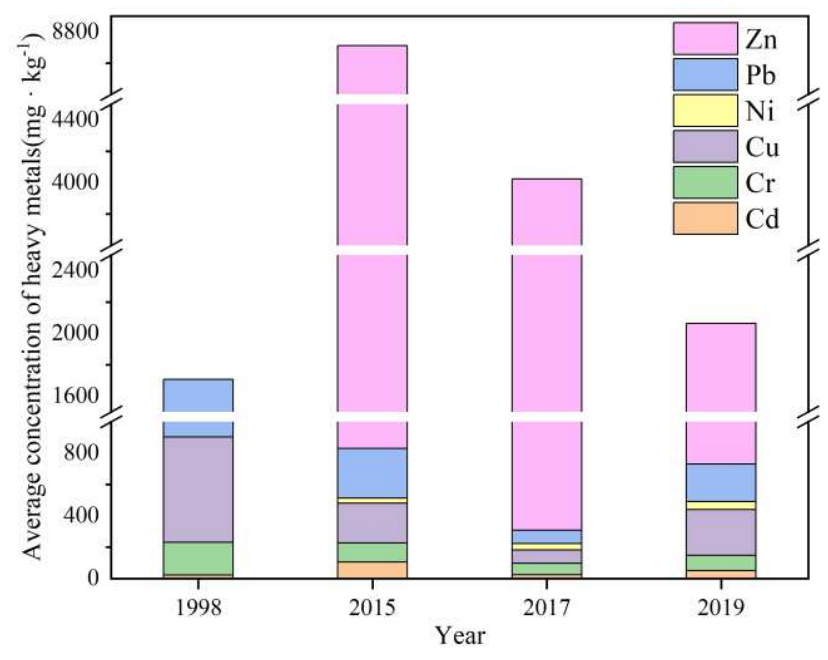

Figure 4. Change in heavy metals concentrations in the sediment from the Huafei River from 1998 to 2019.

to the relocation of industrial enterprises from the old industrial base of Kaifeng, the transformation and upgrading of enterprises, and the renewal of equipment. However, the contents of some heavy metals $(\mathrm{Cu}$ and $\mathrm{Pb})$ increased in 2019 , which may be attributed to the fact that the sampling sites in 
2019 were mostly located in the midstream and downstream sections of the river. Additionally, with regard to the six heavy metals, the order of their mean concentrations for nearly 20 years followed a general trend of: $\mathrm{Zn}>\mathrm{Pb}>\mathrm{Cu}>\mathrm{Cr}>\mathrm{Cd}>\mathrm{Ni}$ as can be seen in Fig. 5, which also indicates that $\mathrm{Zn}, \mathrm{Pb}$ and $\mathrm{Cu}$ dominate the

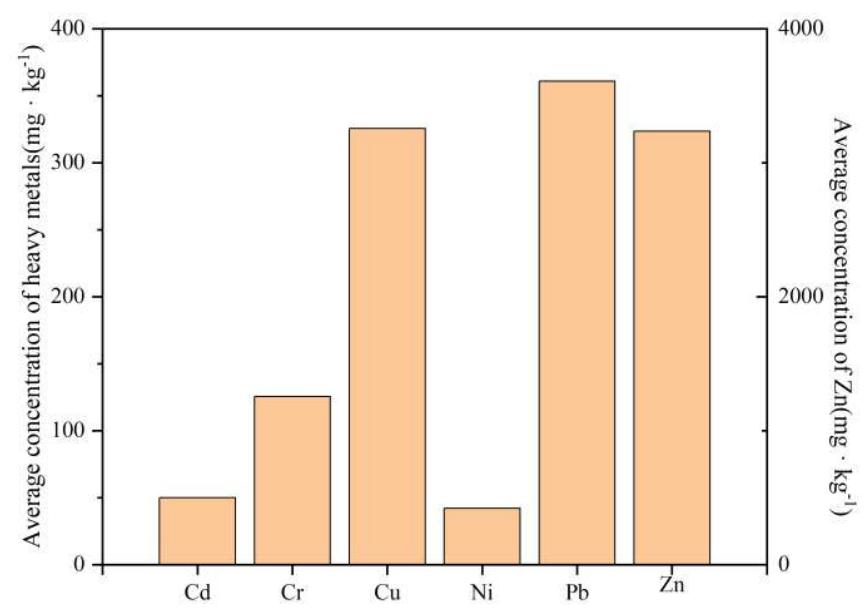

Figure 5. The average concentration of heavy metals over the last 20 years.

heavy metal pollution of the Huafei River. As compared to other heavy metals, the average concentration of $\mathrm{Zn}$ in sediment was found to be higher at more than $3000 \mathrm{mg} \cdot \mathrm{kg}^{-1}$ followed by $\mathrm{Pb}$ and $\mathrm{Cu}$, with both reaching concentrations of more than $300 \mathrm{mg} \cdot \mathrm{kg}^{-1}$.

To identify the main sources of heavy metals in sediments of the Huafei River, a Pearson correlation analysis was used to determine the degree of correlation among heavy metals in river sediments, with correlation coefficients presented in Table 8 , which suggests that $\mathrm{Cd}$ has significant positive correlations with $\mathrm{Cu}$ and $\mathrm{Pb}\left(\mathrm{r}=0.539^{* *}\right.$ and $0.505^{*}$, respectively), indicating a common origin. Except for Cd and As, positive correlations are found between the other six elements, with correlation coefficients ranging from $0.627^{* *}$ to $0.985^{* *}$. Similarly, they may have a common source. 
The results also suggest that As has no apparent correlations with the other metals. This indicates that As might have different sources compared to the other seven elements.

Table 8. The correlation coefficients between heavy metals in sediments of the Huafei River.

\begin{tabular}{lllllllll}
\hline Pearson correlation & $\mathrm{Cd}$ & $\mathrm{Cr}$ & $\mathrm{Cu}$ & $\mathrm{Ni}$ & $\mathrm{Pb}$ & $\mathrm{Zn}$ & $\mathrm{Hg}$ & $\mathrm{As}$ \\
\hline $\mathrm{Cd}$ & 1 & & & & & & & \\
$\mathrm{Cr}$ & 0.242 & 1 & & & & & & \\
$\mathrm{Cu}$ & $0.539^{* *}$ & $0.719^{* *}$ & 1 & & & & & \\
$\mathrm{Ni}$ & 0.332 & $0.837^{* *}$ & $0.934^{* *}$ & 1 & & & & \\
$\mathrm{~Pb}$ & $0.505^{*}$ & $0.670^{* *}$ & $0.961^{* *}$ & $0.910^{* *}$ & 1 & & & \\
$\mathrm{Zn}$ & $0.446^{*}$ & $0.689^{* *}$ & $0.933^{* *}$ & $0.907^{* *}$ & $0.985^{* *}$ & 1 & & \\
$\mathrm{Hg}$ & 0.267 & $0.627^{* *}$ & $0.819^{* *}$ & $0.819^{* *}$ & $0.883^{* *}$ & $0.908^{* *}$ & 1 & \\
$\mathrm{As}$ & -0.204 & 0.136 & -0.093 & -0.046 & -0.181 & -0.188 & -0.197 & 1 \\
\hline
\end{tabular}

Note: ${ }^{*}$ At the 0.05 significance level; ${ }^{* *}$ At the 0.01 significance level.

Using varimax rotation with Z-score Standardization, PCA was performed on the heavy metal data minimizing the sum of the variance of the factor coefficients. This technique divides variables into different groups. In this study, PCA involving the heavy metals was used to further analyze the source of heavy metals. The Keiser-Meyer-Olkin $(\mathrm{KMO}, 0.793)^{32}$ and Bartlett's tests $(<0.001)^{33}$ indicate that the eight heavy metal concentrations are suitable for PCA. In Table 9, 92.65\% of the cumulative variance can be explained through the three principal components (PCs). The rotated component matrix indicates that $\mathrm{Cr}, \mathrm{Cu}, \mathrm{Ni}, \mathrm{Pb}, \mathrm{Zn}, \mathrm{Hg}$ are strongly associated in the $\mathrm{PC} 1$ with respective high loadings of $(0.827,0.904,0.963,0.920,0.937$ and 0.913$)$. PC2 accounts for $15.66 \%$ of the total variance and can be explained through the high loading for $\mathrm{Cd}(0.965)$. PC3, dominated by As with a high loading of 0.968 , accounts for $14.02 \%$. The spatial scatter diagram of PCA (Fig. 6) displays the clustering results of heavy metals more intuitively.

Table 9. Rotated component matrix of factor loadings.

\begin{tabular}{llll}
\hline Elements & 1 & 2 & 3 \\
\hline $\mathrm{Cd}$ & 0.221 & 0.965 & -0.098 \\
$\mathrm{Cr}$ & 0.827 & 0.062 & 0.294 \\
\hline
\end{tabular}




\begin{tabular}{llll}
\hline $\mathrm{Cu}$ & 0.904 & 0.368 & -0.022 \\
$\mathrm{Ni}$ & 0.963 & 0.134 & 0.042 \\
$\mathrm{~Pb}$ & 0.920 & 0.313 & -0.140 \\
$\mathrm{Zn}$ & 0.937 & 0.239 & -0.153 \\
$\mathrm{Hg}$ & 0.913 & 0.029 & -0.209 \\
$\mathrm{As}$ & -0.050 & -0.095 & 0.968 \\
Eigenvalue (total) & 5.038 & 1.253 & 1.122 \\
$\%$ of total variance & 62.974 & 15.659 & 14.020 \\
$\%$ of cumulative & 62.974 & 78.633 & 92.653 \\
\hline
\end{tabular}

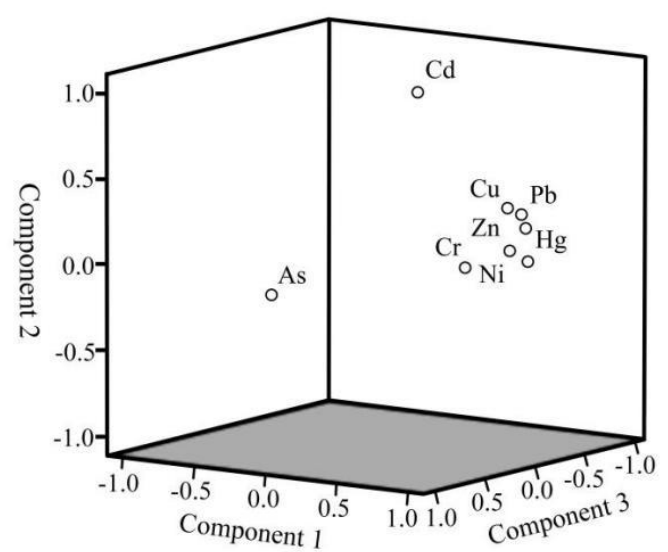

Figure 6. Plot of loading of three principal components in PCA results.

Cluster analysis (CA) was applied using Ward's method and taking the Euclidean distance as a measure, to analyze the source of heavy metals in more significant detail. The CA heat map of heavy metals in river sediments, as shown in Fig. 7 suggests the existence of three clusters: (1) comprising $\mathrm{Ni}, \mathrm{Cu}, \mathrm{Zn}, \mathrm{Pb}, \mathrm{Hg}$, and $\mathrm{Cr}$; (2) Cd; (3) As. Note that the results from CA agree with those derived from PCA. 


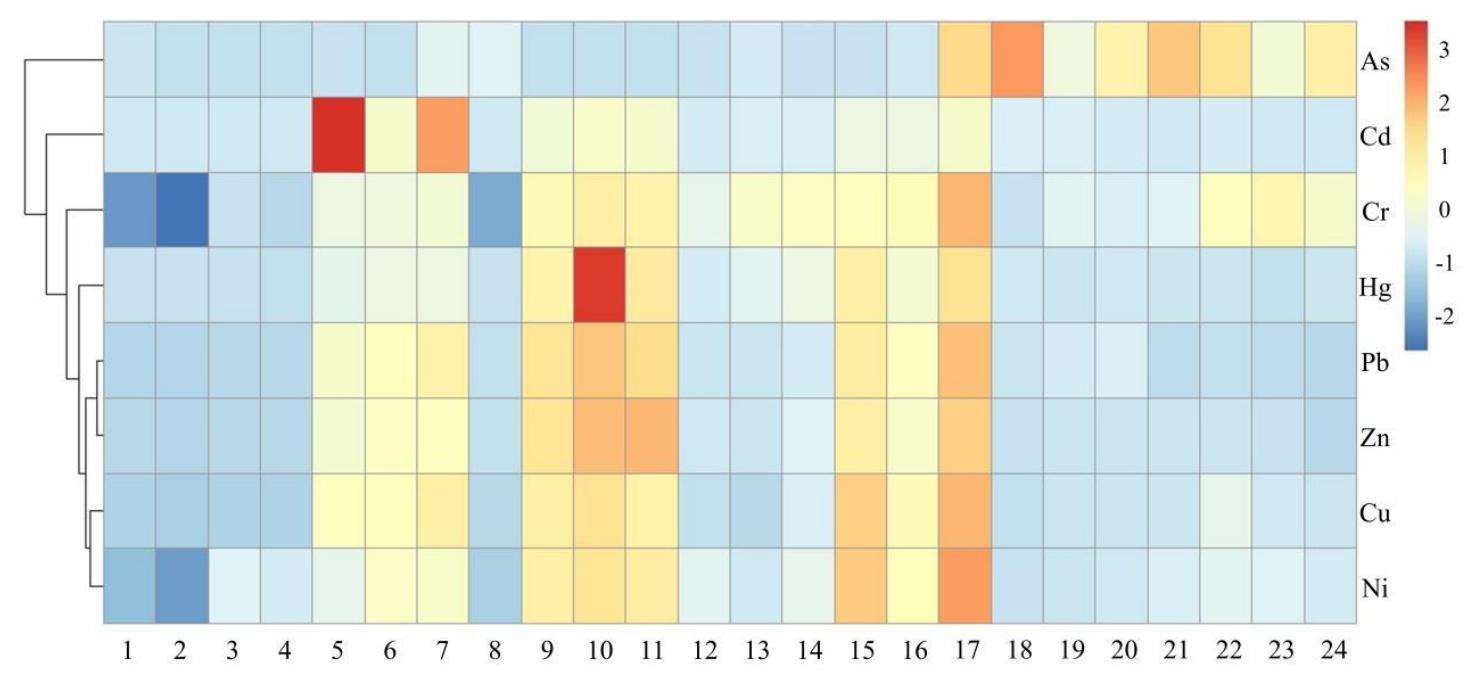

Figure 7. Cluster analysis heat map of heavy metals in sediments from the Huafei River.

According to the results of Pearson's correlation, principal component, and cluster analyses, the sources of heavy metals divided into three main categories. The first category comprises $\mathrm{Cr}, \mathrm{Cu}$, $\mathrm{Ni}, \mathrm{Pb}, \mathrm{Zn}$ and $\mathrm{Hg}$; $\mathrm{Cd}$ is in the second category; whilst As is in the third category. In a previous study, industrial activities were reported as playing an important role in contaminations with $\mathrm{Cu}, \mathrm{Zn}$ and $\mathrm{Pb}^{34}$. Similar studies demonstrated that $\mathrm{Zn}, \mathrm{Cr}, \mathrm{Ni}, \mathrm{Hg}$ and $\mathrm{Cu}$ contaminations were mainly related to industrial activities ${ }^{35,36}$. Moreover, $\mathrm{Ji}$ et $\mathrm{al}^{37}$ also reported that $\mathrm{Pb}, \mathrm{Zn}$ and $\mathrm{Ni}$ contaminations were associated with industrial production, especially with industrial wastewater from factories. In this research, located in the old industrial zone of Kaifeng, the Huafei River has been heavily affected by industrial activities, although several factories have moved out of the area and in those remaining, equipment has been updated in recent years. There are many industrial enterprises along the midstream and downstream sections of the river, such as a paper factory, pharmaceutical factory, fertilizer factory, instrument manufacturer, and a metal smelting plant, etc. The industrial wastewater produced by these enterprises is discharged directly into the river without even the simplest form of treatment, whilst fly ash is deposited in the river through the atmosphere, resulting in the accumulation of heavy metals in the river sediments. However, the pollution from 
$\mathrm{Cu}$ and $\mathrm{Pb}$ mainly originates from traffic sources ${ }^{34,35}$. In particular, $\mathrm{Cu}$ and $\mathrm{Pb}$ are released into the environment as a result of the wear and subsequent loss of material from auto parts as well as through the use of lubricants and petrol ${ }^{35,38}$. Moreover, Kumar et al ${ }^{39}$ concluded that traffic emissions are also one of the sources of $\mathrm{Pb}, \mathrm{Zn}$ and Ni pollution. The Longhai Railway, the G220 National Highway, and the Xincao Road cross the Huafei River, and there are numerous auto-repair plants along the river, all of which contribute to the heavy metal pollution in the river sediments. However, it is suggested that $\mathrm{Cr}$ and $\mathrm{Ni}$ came from natural origins $\mathrm{s}^{31,36,40-43}$. In the present study, the mean concentrations of $\mathrm{Cr}$ and $\mathrm{Ni}$ are 1.50 and 1.78 times larger than the local background values, respectively; results that are nevertheless not high. Besides, the $\mathrm{CVs}$ of $\mathrm{Cr}$ and $\mathrm{Ni}$ are in the relatively low spatial variability category, with recorded measurements of $32 \%$ and $43 \%$, respectively (Table 5). Therefore, natural sources are another major source for $\mathrm{Cr}$ and $\mathrm{Ni}$ in the sediments. As mentioned above, the first category is recognized as industrial activities, followed by traffic sources and then natural sources.

In the second category, the only metal element found is $\mathrm{Cd}$, and its accumulation in sediment is reported to stem from industrial activities ${ }^{34,36,39}$. Sewage treatment and the sewage outlets of various plants contribute to $\mathrm{Cd}$ contamination ${ }^{37,44}$. Moreover, an additional source of $\mathrm{Cd}$ in sediment was found to emanate from agricultural activities, through the intensive use of chemical fertilizers and pesticides ${ }^{39,43,45}$. Furthermore, besides factories, there is a lot of farmland in the vicinity of the river, which potentially contributes to the $\mathrm{Cd}$ contamination. Thus, the high concentration of $\mathrm{Cd}$ is effectively derived from a combination of industrial and agricultural sources.

In the third category, arsenic (As) is often associated with industrial activities. Industrial sewage, coal combustion and mineral-smelting activities are all related to As pollution in the river 
sediment ${ }^{31,36,41}$. Therefore, a variety of industrial activities have a significant impact on As pollution.

In summary, the heavy metal contamination is derived from industrial activities, agricultural sources, traffic sources and natural sources, but especially from industrial sources.

\section{Conclusions}

The motivation for this study is to provide theoretical references for the effective control and scientific management of heavy metal pollution in the Huafei River and its surrounding areas. To accomplish this, the study focused on the 3 objectives, detailed in the Introduction, and summarized as: 1) the collection and analysis of sediment samples from the Huafei river, 2) evaluation of the degree of contamination and assessment of ecological risks in the river incorporating data from other research over the past 20 years and, 3) identification of the possible sources of pollution. From the findings and discussion pursuant to these objectives, we can, therefore, make the following conclusions:

(1) The average values of $\mathrm{pH}, \mathrm{OM}, \mathrm{TN}$ and TP were $7.73,5932.59 \mathrm{mg} \cdot \mathrm{kg}^{-1}, 2089.76 \mathrm{mg} \cdot \mathrm{kg}^{-1}$ and $786.58 \mathrm{mg} \cdot \mathrm{kg}^{-1}$, respectively. The concentrations of $\mathrm{As}, \mathrm{Cd}, \mathrm{Cr}, \mathrm{Cu}, \mathrm{Hg}, \mathrm{Ni}, \mathrm{Pb}$ and $\mathrm{Zn}$ are over $2.86,563.99,1.50,12.77,312.82,1.78,11.58$ and 19.69 times higher than the local background value, respectively.

(2) The degree of pollution of each metal in terms of $I_{\mathrm{geo}}$ in the Huafei River sediment decreased in the following order: $\mathrm{Hg}>\mathrm{Cd}>\mathrm{Zn}>\mathrm{Cu}>\mathrm{Pb}>\mathrm{Ni}>\mathrm{As}>\mathrm{Cr}$. About $66.7 \%$ of the sampling sites showed above class 5 pollution (strongly to extremely polluted). Spatially, the $I_{\text {geo }}$ values exhibit the most severe pollution at sites $7,10,11$ and 16 , which reached class 5 (strongly to extremely polluted). Overall, the midstream and downstream sections of the Huafei river are strongly polluted.

(3) The average value of RI in the research was 29614.48 , with a very high potential ecological 
risk. Additionally, the mean values of $E$ decreased in the following sequence: $\mathrm{Cd}>\mathrm{Hg}>\mathrm{Cu}>\mathrm{Pb}>$ As $>\mathrm{Zn}>\mathrm{Ni}>\mathrm{Cr}$. Moreover, $\mathrm{Hg}$ and $\mathrm{Cd}$ were the dominant factors for RI. All Hg sampling sites and approximately $79 \%$ of Cd sampling sites exhibited very high ecological risk (class 5). Spatially, the midstream and downstream sections of the river (sites 5-24) showed the highest potential ecological risk.

(4) For nearly 20 years, the concentrations of $\mathrm{Cu}$ and $\mathrm{Pb}$ decreased significantly from 1998 to 2017, and then increased in 2019; however, the concentration of $\mathrm{Zn}$ showed a continuous decreasing trend.

(5) As the source identification showed, the heavy metals in the sediments of the Huafei river are derived from industrial activities, agricultural sources, traffic sources and natural sources, especially industrial sources. $\mathrm{Cr}, \mathrm{Cu}, \mathrm{Ni}, \mathrm{Pb}, \mathrm{Zn}$ and $\mathrm{Hg}$ contaminants were mainly derived from industrial activities, traffic sources and natural sources; $\mathrm{Cd}$ mainly originated from industrial and agricultural activities; As sources were mainly associated with industrial activities.

\section{References}

1. Chabukdhara, M. \& Nema, A. K. Assessment of heavy metal contamination in Hindon River sediments: A chemometric and geochemical approach. Chemosphere 87(8), 945-953 (2012).

2. Dash, S., Borah, S. S. \& Kalamdhad, A. S. Heavy metal pollution and potential ecological risk assessment for surficial sediments of Deepor Beel, India. Ecol. Indic. 122, 107265 (2020).

3. Du, Y. M. et al. Accumulation and translocation of heavy metals in water hyacinth: Maximising the use of green resources to remediate sites impacted by e-waste recycling activities. Ecol. Indic. 115, 106384 (2020).

4. Zeng, Y. S., Bi, C. J., Jia, J. P., Deng, L. \& Chen, Z. L. Impact of intensive land use on heavy metal concentrations and ecological risks in an urbanized river network of Shanghai. Ecol. Indic. 116, 106501 (2020). 
5. Duodu, G. O., Goonetilleke, A. \& Ayoko, G. A. Potential bioavailability assessment, source apportionment and ecological risk of heavy metals in the sediment of Brisbane River estuary, Australia. Mar. Pollut. Bull. 117(12), 523-531 (2017).

6. Cui, S. et al. Heavy Metals in Sediment from the Urban and Rural Rivers in Harbin City, Northeast China. Int. J. Environ. Res. Public Health 16, 4313 (2019).

7. Kayembe, J. M. et al. Assessment of water quality and time accumulation of heavy metals in the sediments of tropical urban rivers: Case of Bumbu River and Kokolo Canal, Kinshasa City, Democratic Republic of the Congo. J. Afr. Earth Sci. 147, 536-543 (2018).

8. Liu, D. X., Li, Y. M., Ma, J. H., Li, C. \& Chen, X. Heavy Metal Pollution in Urban Soil from 1994 to 2012 in Kaifeng City, China. Air Soil Pollut. 227, 154.1-154.10 (2016a).

9. Liu, D. X., Ma, J. H., Sun, Y. L. \& Li, Y. M. Spatial distribution of soil magnetic susceptibility and correlation with heavy metal pollution in Kaifeng City, China. Catena 139, 53-60 (2016b).

10. Chai, L. et al. Pollution characteristics, spatial distributions, and source apportionment of heavy metals in cultivated soil in Lanzhou, China. Ecol. Indic. 125, 107507 (2021).

11. Bai, J. H. et al. Spatial and temporal dynamics of heavy metal pollution and source identification in sediment cores from the short-term flooding riparian wetlands in a Chinese delta. Environ. Pollut. 219, 379-388 (2016).

12. Nguyen, B. T. et al. Seasonal, spatial variation, and pollution sources of heavy metals in the sediment of the Saigon River, Vietnam. Environ. Pollut. 256, 1-12 (2020).

13. Chen, Z. F., Xu, W., Hua, Y. X., Pei, J. C. \& Yang, Y. J. Ecological risk assessment and isotope source analysis of heavy metals accumulated in sediments of Kaifeng urban rivers. Acta Scientiae Circumstantiae. 40, 13211330 (2020). ((In Chinese with English Abstract))

14. Zuo, S. D., Dai, S. Q., Li, Y. Y., Tian, J. F. \& Ren, Y. Analysis of Heavy Metal Sources in the Soil of Riverbanks 
Across an Urbanization Gradient. Int. J. Environ. Res. Public Health 15, 2175 (2018).

15. Ma, T., Sheng, Y. Q., Meng, Y. J. \& Sun, J. Z. Multistage remediation of heavy metal contaminated river sediments in a mining region based on particle size. Chemosphere 225, 83-92 (2019).

16. Hakanson. An ecological risk index for aquatic pollution control: a sedimentological approach. Water Res. 14, 975-1001 (1980).

17. Ma, J. H., Han, C. X. \& Jiang, Y. L. Some problems in the application of potential ecological risk index method. Geogr. Res. 39, 1233-1241 (2020). ((In Chinese with English Abstract))

18. Workineh, T. A., Tekleweini, G., Xu, Q., Tang, X. J. \& Wang, J. Concentrations, Distribution, Sources and Ecological Risk Assessment of Trace Elements in Soils from Wuhan, Central China. Int. J. Environ. Res. Public Health 15, 2873 (2018).

19. Zheng, X. J. et al. Ecological risk assessment of heavy metals in the vicinity of Tungsten Mining Areas, Southern Jiangxi Province. An. Inter. J. 29, 665-679 (2020).

20. Han, J. X. Pollution and migration of heavy metals of the soil-wheat system at sewage irrigation region of Huafei river in Kaifeng city. Dissertation, Henan University (2003) ((In Chinese with English Abstract))

21. Li, Y. M., Ma, J. H., Liu, D. X., Sun, Y. L. \& Chen, Y. F. Assessment of Heavy Metal Pollution and Potential Ecological Risks of Urban Soils in Kaifeng City, China. Environ. Sci. 36, 1037-1044 (2015). ((In Chinese with English Abstract))

22. Han, J. X. \& Ma, J. H. Polluting, transferring and accumulating of heavy metals in soil-wheat system in sewage irrigation region: a case study in Huafei River in Kaifeng, Guangdong. Ecol. Environ. pp. 578-580+591 (2004).

((In Chinese with English Abstract))

23. Du, X. L., Ma, J. H., Lv, C. H. \& Li, W. J. Soil animals and their responses to soil heavy metal pollution in sewage irrigated farmland:A case study of the sewage irrigated area of Huafei River, Kaifeng City. Geogr. Res. 
29, 617-628 (2010).

24. Du, P., Ma, J. H. \& Han, J. X. Potential ecological risk assessment of heavy metals in soil of Fengfeng River sewage irrigation area. Earth Environ. 37, 436-440 (2009). ((In Chinese with English Abstract))

25. Wang, H. T., Zhang, J. H., Ding, S. F., Guo, T. F. \& Fu, X. Z. Distribution characteristics, sources identification and risk assessment of heavy metals in surface sediments of urban rivers in Kaifeng. Acta Scientiae Circumstantiae 36, 4520-4530 (2016). ((In Chinese with English Abstract))

26. Müller, G. Index of geoaccumulation in sediments of the Rhine River. Geojournal 2, 108-118 (1969).

27. Atibu, E. K., Lacroix, P., Sivalingam, P., Ray, N. \& Poté, J. High contamination in the areas surrounding abandoned mines and mining activities: An impact assessment of the Dilala, Luilu and Mpingiri Rivers, Democratic Republic of the Congo. Chemosphere 191, 1008-1020 (2017).

28. Niu, Y. et al. Meta analysis of heavy metal pollution and sources in surface sediments of Lake Taihu, China. Sci. Total Environ. 700, 134509 (2020).

29. Zhang, G. L. et al. Heavy metal fractions and ecological risk assessment in sediments from urban, rural and reclamation-affected rivers of the Pearl River Estuary, China. Chemosphere 184, 278-288 (2017).

30. Environmental Protection Agency. The background contents of trace elements in Chinese soil. Beijing, China Environmental Science Press pp. 1-223 (1990). (in Chinese)

31. Xu, J. Y. et al. Distribution, risk assessment, and source analysis of heavy metals in sediment of rivers located in the hilly area of southern China. J. Soil Sediment 19, 3608-3619 (2019).

32. Kaiser, F. H. The Application of Electronic Computers to Factor Analysis. Educ. Psychol. Meas. 20, 141-151 (1960).

33. Dalal, S. G., Shirodkar, P. V., Jagtap, T. G., Naik, B. G. \& Rao, G. S. Evaluation of significant sources 
influencing the variation of water quality of Kandla creek, Gulf of Katchchh, using PCA. Environ. Monit. Assess. 163, 49-56 (2010).

34. Luo, L. L. et al. Assessment of the Geographical Detector Method for investigating heavy metal source apportionment in an urban watershed of Eastern China. Sci. Total Environ. 653, 714 (2019).

35. Chen, T., Chang, Q. R., Liu, J., Clevers, J. G. P. W. \& Kooistra, L. Identification of soil heavy metal sources and improvement in spatial mapping based on soil spectral information: A case study in northwest China. Sci. Total Environ. 565, 155-164 (2016).

36. Liang, J. et al. Spatial distribution and source identification of heavy metals in surface soils in a typical coal mine city, Lianyuan, China. Environ. Pollut. 225, 681 (2017).

37. Ji, Z. H. et al. Distribution, ecological risk and source identification of heavy metals in sediments from the Baiyangdian Lake, Northern China. Chemosphere 237, 124425 (2019).

38. Smichowski, P., Gomez, D., Frazzoli, C. \& Caroli, S. Traffic-Related Elements in Airborne Particulate Matter. Appl. Spectrosc. Rev. 43, 23-49 (2008).

39. Kumar, V. et al. A review of ecological risk assessment and associated health risks with heavy metals in sediment from India. Int. J. Sediment Res. 35, 516-526 (2020).

40. Dong, B. et al. Multiple methods for the identification of heavy metal sources in cropland soils from a resourcebased region. Sci. Total Environ. 651, 3127-3138 (2018).

41. Ke, X. et al. Ecological risk assessment and source identification for heavy metals in surface sediment from the Liaohe River protected area, China. Chemosphere 175, 473-481 (2017).

42. Tian, K. et al. Ecological risk assessment of heavy metals in sediments and water from the coastal areas of the Bohai Sea and the Yellow Sea. Environ. Int. 136 (2020).

43. Zhang, Z. X. et al. Assessment of heavy metal contamination, distribution and source identification in the 
sediments from the Zijiang River, China. Sci. Total Environ. 645, 235-243 (2018).

44. Yin, X. Z. et al. Cadmium isotope constraints on heavy metal sources in a riverine system impacted by multiple anthropogenic activities. Sci. Total Environ. 750, 141233 (2021).

45. Dai, L. J. et al. Multivariate geostatistical analysis and source identification of heavy metals in the sediment of Poyang Lake in China. Sci. Total Environ. 621, 1433-1444 (2018).

\section{Acknowledgements}

We are grateful to Dr John Turnbull for helping to improve the manuscript with comments on a draft of the paper. This work was funded by National Natural Science Foundation of China (41601197), China Postdoctoral Science Foundation (2019M652520), National College Students' Innovative Entrepreneurial Training Plan Program (202010475019) and Program for Innovative Talents of Zhongyuan Postdoctoral.

\section{Author contribution}

Bingyan Jin: Writing - Original Draft, Visualization, Formal analysis; Jinling Wang: Writing - Original Draft; Wei Lou: Methodology, Formal analysis; Liren Wang: Formal analysis; Jinlong Xu: Visualization, Investigation; Jing Qian: Investigation, Data Curation; Dexin Liu: Conceptualization, Writing - Review \& Editing, Project administration; Jianbiao Peng: Investigation, Resources; Qingxia Ma: Writing Review \& Editing.

\section{Data availability}

The data sets used and/or analyzed during the current study are available from the corresponding author on reasonable request.

\section{Declarations}

Ethics approval and consent to participate Not applicable. 
Consent for publication All authors agree to have this manuscript published in this journal.

Competing interest The authors declare no competing interests.

\section{Figure legends}

Figure 1. Sampling location map of the study area.

Figure 2. The contents of heavy metals in the sediments from the Huafei River

Figure 3. Spatial distribution of geo-accumulation indexes of heavy metals in sediments from the Huafei River.

Figure 4. Change in heavy metals concentrations in the sediment from the Huafei River from 1998 to 2019.

Figure 5. The average concentration of heavy metals over the last 20 years.

Figure 6. Plot of loading of three principal components in PCA results.

Figure 7. Cluster analysis heat map of heavy metals in sediments from the Huafei River.

Table 1. The geo-accumulation index classification standard.

Table 2. The geo-chemical background value $C_{n}^{i}$ and the toxic response factor $T_{r}^{i}$.

Table 3. The adjusted $E$ and RI classification standards.

Table 4. Values of physicochemical properties in sediments of the Huafei River.

Table 5. Descriptive statistics of heavy metal concentrations $\left(\mathrm{mg} \cdot \mathrm{kg}^{-1}\right)$.

Table 6. Heavy metal accumulation index and classification of sediment at each sampling site.

Table 7. The potential ecological risk indexes of heavy metals in sediments from the Huafei River.

Table 8. The correlation coefficients between heavy metals in sediments of the Huafei River.

Table 9. Rotated component matrix of factor loadings. 